\title{
The Holistic Integrated Approach of Early Childhood Education and Development in Indonesia: Between Issues and Possibilities
}

\author{
Nurman Siagian ${ }^{1, *}$ Vina Adriany ${ }^{2}$ \\ ${ }^{1}$ Kolaborasi Masyarakat dan Pelayanan untuk Kesejahteraan (KOMPAK), Jakarta, Indonesia \\ ${ }^{2}$ Department of Early Childhood education, Universitas Pendidikan Indonesia \\ *Corresponding author. Email: nurman.siagian@kompak.or.id
}

\begin{abstract}
Early Childhood Education (ECE) has important roles for young children and country's development. Hence, the Indonesian government has attempted to develop holistic integrated services from various sectors to optimize early childhood education which are able to fulfill a child's rights. This paper aims to examine the implementation of the holistic integrated approach of Early Childhood Education and development (ECED) in Indonesia as known as PAUD HI or Holistic Integrated ECE (HI-ECE). It used document analysis and on-site visits that include interviews as well as focus group discussion with various stakeholders in three districts in Indonesia. It would figure out some issues and possibilities when the policy is being adopted. The findings suggested that there were three main issues regarding the implementation of the policy, namely understanding, integration and governance issues. Then, it also suggested some best practices of policy implementation such as the most implemented policy when there was a cooperation at countryside level. Moreover, it could be done optimally when there was a responsive approach to local and district needs. Thus, the policy could be relevant to them. Keywords: Early childhood education and development, holistic, integrated, governance
\end{abstract}

\section{INTRODUCTION}

For the past 20 years, the Indonesian government has put particular attention to the Early Childhood Education and Development (ECED) in the country (Adriany \& Saefullah, 2015). The government's focus to ECED can be seen by the establishment of the ECED directorate within the Ministry of Education in 2010 (Formen, 2017) and the government's cooperation with various global donor institutions such as the World Bank, UNESCO, and UNICEF and the ECED sectors (Adriany, 2018). At the same time, there is also a global need as indicated in the Sustainable Development Goals (SDGs) 2030. one of SDGs' indicators is giving a full access and participation to high quality ECED for achieving a high-quality education.

One of the latest strategies adopted by the Indonesian government to improve the quality of ECED is by launching the holistic integrated ECED (HI-ECED) program. The program aims to integrate various services on ECED such as education, health, care, child-protection and child wellbeing. Under this program, ECED services are not seen as a responsibility of one single ministry, but rather they are the obligation of various ministries as well as nongovernmental organizations (Indonesian Ministry of National Development Planning, Republic of Indonesia [BAPPENAS], 2013). The objective of the HI- ECED is obvious to provide more accessible ECED to all Indonesian children.

Within the holistic integrated approach, ECED services are not only confined to the education aspect. Rather it takes into account different services such as health and it also emphasis to the services related to care and child protection (BAPENAS, 2018).

Despite all the efforts taken by the government, there are still some issues surrounding the ECED services in the country. The first issue is access. The latest data from the Ministry of Education and Culture indicated that the access to ECED centres in Indonesia is only $34.19 \%$ (Center for Educational data and Statistics and culture, 2019). The data also reveal that geographical disparities make some children have limited access to ECED services. The second issue is a quality of the ECED centres. In Indonesia, most of the them are still using teacher-centred approach that emphasis on the academic activities such as reading and writing rather than playing (Kurniati, Adriany, \& Yulindrasari, 2007). The third issue is about health. The study revealed that most Indonesian children are suffering from stunting (Anggunpaud, 2018; Ministry of Health, Republic of Indonesia [Kemenkes RI], 2018) and lack of nutrition (Kemenkes RI, 2018a). The fourth issue is related to the fulfillment of child rights. It can be seen that many children in the rural areas in Indonesia still do not have the birth certificate (Ministry of Empowerment and Child 
Protection, Republic of Indonesia [Kemenpppa, RI], 2018). As the result, children who do not have birth certificate are often having problem when they want to enroll in the ECED centres later on. At the same time, the number of violence against children is also still quite high in the rural areas in Indonesia (Kemenpppa RI, 2016). Hence, the aim of this paper is to explore the extent to which the implementation of the HI-ECED approach could help the government in dealing with those problems. It also intends to analyse the implementation of the approach critically. It is expected the finding would illuminate the obstacles faced and would provide directions to navigate the program better. This research was conducted by KOMPAK, a program funded by the Australian government and the National Planning Agency (BAPPENAS).

\section{BEYOND PYSCHOLOGICAL MODEL OF ECED: APPLYING ECOLOGICAL APPROACH IN UNDERSTANDING HOLISTIC INTEGRATED ECED}

The theories and practices of ECED in Indonesia have been influenced by the psychological model of children's development (Adriany, 2016). While the model has provided ECED practitioners with perspectives and knowledge on how to understand young children development, but the model is merely focusing on the child individuality (Burman, 2008). Children development is seen as the result of individual internal traits such as personality, motivation, intelligence and so forth. By emphasizing to the child as an individual, the psychology model tends to overlook the social-factors such as poverty, racism, gender, social-class, family factors, and global inequities that may also contribute to the children development (Penn, 2008).

It is the ecological model of children development, established by Bronfenbrenner (1979) that articulates the need to take into consideration larger social-political discourse understanding in children's development. Within this framework, children are always in a specific cultural and historical context that affects their childhood through particular ways. The ecological model argues that children's development is first influenced by their microsystem that includes the close environment such as family. In addition, there is also a mesosystem that incorporates any institution such as school, kindergarten, day care, etc. Besides, there are also three larger systems, consist of the exosystem, macrosystem, and chronosystem. Each represents larger social, economic, cultural and political systems such as the government's policies, cultural values, and normative as well as normative transition that indirectly affect the children's development (Bronfenbrenner, 1979).
The ecological model has circuitously influenced the development of the HI-ECED program. The history of the program goes back to the conference organized by the Organization for Economic Cooperation and Development (OECD) with the Swedish government in 2001 (Haddad, 2006). The conference aimed to provide a forum to present practices of ECED in various countries. The discussion in the conference recommended that the need for paradigm shift in understanding and implementing ECED (OECD, 2004). Among the recommendations made in the conference are: 1) There is a need to have an integrated ECED services; 2) There is a need to have a cross and multi sectoral in implementing ECED programs; 3) It is a must to have equal access to high quality ECED services; 4) There is a need to have a public investment to ECED services; 5) There is a need to have a full participation from the community; 6) There is a need to improve teachers' competencies and professionalism; 7) There has to be a monitoring and evaluative system to measure the effectiveness of ECED services; and 8) There is a need to have general framework to help stakeholders implement ECED programs.

This new paradigm, as mentioned earlier, requires a change in seeing ECED services. ECED is not only the responsibility of the parents or one particular ministry, but rather it has to become attention of various stakeholders and ministries. The program invites the state to be more tangible in fulfilling the rights and needs of young children. It is also important to note that the development of the HIECED program consists of information regarding children's perspectives. Within this viewpoint, a child has fundamental and basic rights (Haddad, 2006). In Indonesia, these rights related to high quality education, health and nutrition, as well as the right for care, child-protection, and well-being.

\section{RESEARCH METHODS}

This paper uses qualitative approach. Specifically, a case study. It was selected because the researchers analyzed and compared how the HI-ECED program was implemented in various districts (Swanborn, 2010). For the purpose of this research, the researchers did on-site visitation from July to September 2019 to 7 different areas in Indonesia. There were Sumatera, Java, Kalimantan, Nusa Tenggara, and Papua. The participants included stakeholders represented ECED institutions both from the government as well as grassroots support organizations such as; Ministry for Human Development and Cultural Affairs; Directorate of Early Childhood Education and Community Education, representation from a sub-district with responsibility for education, health, social affairs, population and civil registration; as well as regional financial and asset management services; National Population and Family 
Planning Agency; and Non-Government Organizations (NGOs) .

During visitation, the researchers visited various ECED centres, including integrated post-services (POSYANDU), as well as interviewing the participants. In addition, focus group discussion was also organized. The summary of our research sites can be seen in the table 1 .

Tabel 1 Research sites

\begin{tabular}{|c|l|c|}
\hline No. & Research Cites & Times \\
\hline $\mathbf{1 .}$ & Districts of Kupang, Belu, North Lombok, West Sumba, and Central Sumba & 4-5 July 2019 \\
\hline $\mathbf{2 .}$ & District of Sentani, Papua & 17 July 2019 \\
\hline $\mathbf{3 .}$ & District of Lanny Jaya, Papua & 18-19 July 2019 \\
\hline $\mathbf{4 .}$ & District of Pemalang, Central Java & 29-30 July 2019 \\
\hline $\mathbf{5 .}$ & District of Bantul, Yogyakarta & 5 July 2019 \\
\hline $\mathbf{6 .}$ & District of Magelang, Central Java & 6 July 2019 \\
\hline $\mathbf{7 .}$ & District of Melawi, West Kalimantan & 9-11 September 2019 \\
\hline
\end{tabular}

\section{RESULT AND DISCUSSION}

The finding revealed that the implementation of the HIECED program is still facing obstacles. The three main issues found in this study are

\subsection{Lack of Understanding the Concept of Holistic Integrated ECED}

The finding suggests that apparently there is a lack of understandings among various stakeholders regarding the notion of the HI- ECED. For example, during the focus group discussion in Lanny Jaya, Papua, many participants, did not know about the concept of HI-ECED. In Pemalang, the participants were also not sure whether the term of integrated service includes cross-sectoral activities, or it refers to a specific new program within ECED centres. This resonates with the argument made by Yulindrasari (2012) where she states that many ECED teachers are still confused with the notion of holistic integrated services. The result is

\section{Tabel 2 Focus of services}

also in line with another research conducted by Wulandari, Supriyati, and Jalal (2018) in which they also found that many teachers and stakeholders of ECED services did not understand fully the meaning of the holistic integrated approach.

\subsection{Issue of Integrated Services}

The second finding shows that another issue of the implementation of the HI- ECED program, lies in the fact that the services are not fully integrated. In each district, it is found that each district likely only focuses to one or two services. Only districts such as Bantul and Magelang that already have integrated ECED services in education, health, and care as well as child-protection. It can be concluded that other districts only emphasized on one particular service. The summary of each service in district can be seen in the table 2 .

\begin{tabular}{|c|c|c|}
\hline No & District & Focus of Services \\
\hline 1. & Kupang & Education and Health \\
\hline 2. & Belu & Care, child-protection and child well-being \\
\hline 3. & North Lombok & Care, child-protection and child well-being \\
\hline 4. & West Sumba & Health \\
\hline 5. & Central Sumba & Education \\
\hline 6. & Sentani & Education and Health \\
\hline 7. & Lanny Jaya & Education; Health; Care, child-protection and child well-being \\
\hline 8. & Pemalang & Education; Health; Care, child-protection and child well-being \\
\hline 9 & Bantul & Care, child-protection and child well-being \\
\hline 10. & Magelang
\end{tabular}




\subsection{Governance Issues}

In our research, it is found that another obstacle is related with the issue of governance. As discussed earlier, the implementation of the HI-ECED services requires a paradigm shift that involved seeing ECED as a collective responsibility that requires a cross-sectoral collaboration (Haddad, 2006; Miškeljin, 2013).

The issue is connected with the coordination matter. It appears that are no policies and regulations on a district level. This is not in accordance with the government goals to provide guidance as indicated in the National Action Plan for 2019 (BAPPENAS, 2018). Another issue is related with the extent to which the national framework can interpretated to local and district context. It can be seen that many participants articulated that they need to have a local responsive framework that could help them implementing the HI- ECED program. Yet, the case of Bantul and Magelang prove that a better governance system can lead the districts in adapting the Hi-ECED program.

In addition, the finding shows the absence of the task force in district level that could help them implementing the HIECED in their areas. Again, this illuminates an issue of coordination. This is in line with previous research conducted by Rohita, Fitria, and Nurfadilah (2016) and Rejeki (2011) that demonstrated how the task force could play important roles in implementing the program.

\section{CONCLUSION}

The paper presents a critical approach in analyzing the implementation of HI- ECED program. The finding points out that to make implementation of the program to be successful, there is a need to educate the stakeholders on the value and the importance of the program. Additionally, it reveals the need to have policies, regulation, as well as the task force at the local and district levels so that the program can be implemented according to the need of each district. In other word, there has to be a more effective and efficient governance system (i.e. framework or guideline) for them that could help the district in performing the HI- ECED. Besides, there is also the need provide an assistance and a supervision to the ECED centers, as well as strengthening the capacity of ECE management or teachers allocated from central, district and village funds.

\section{ACKNOWLEDGMENT}

The author would like to express the gratitude to DFAT for initiating and funding this study. The highest appreciation also goes Sularsono, SP,
ME, from the National Planning Agency (BAPPENAS) for the constant guidance and advice throughout the study.

\section{REFERENCES}

Adriany, V. (2016). Gender in pre-school and childcentred ideologies. In J. Warin, I. Wernersson, \& S. Brownhill (Eds.), Men, masculinities and teaching in early childhood education (pp. 70-82). London: Routledge.

Adriany, V. (2018). Neoliberalism and practices of early childhood education in Asia. Policy Futures in Education, 16(1), 3-10. doi: $10.1177 / 1478210317739500$

Adriany, V., \& Saefullah, K. (2015). Deconstructing human capital discourse in early childhood education in Indonesia. In T. Lightfoot-Rueda, R. L. Peach, \& N. Leask (Eds.), Global perspectives on human capital in early childhood education: Reconceptualizing theory, policy, and practice (pp. 159-179). New York: Palgrave Macmillan US.

Anggunpaud. (2018). Tangani masalah stunting perlu komitmen. Retrieved from http://anggunpaud.kemdikbud.go.id/index.php/berita/in dex/20180705132342/Tangani-Masalah-Stunting-PerluKomitmen

Bronfenbrenner, U. (1979). The ecology of human development. Cambridge: Harvard University Press.

Burman, E. (2008). Deconstructing developmental psychology. East Sussex: Routledge.

Formen, A. (2017). In human-capital we trust, on developmentalism we act: The case of indonesian early childhood education policy. In M. Li, J. Fox, \& S. Grieshaber (Eds.), Contemporary issues and challenge in early childhood education in the Asia-Pacific region (pp. 125-142). Singapore: Springer Singapore.

Haddad, L. (2006). Integrated policies for early childhood education and care: Challenges, pitfalls and possibilities. Cadernos de Pesquisa, 36(129), 519-546.

Kementerian Perencanaan Pembangunan Nasional Republik Indonesia/Badan Perencanaan Pembangunan Nasional (BAPPENAS). (2013). Studi strategi pengembangan anak usia dini di Indonesia. Jakarta: Kementerian Perencanaan Pembangunan Nasional Republik Indonesia/Badan Perencanaan Pembangunan Nasional (BAPPENAS). 
Kementerian Pemberdayaan Perempuan dan Perlindungan Anak Repulik Indonesia (Kemenpppa RI). (2016). Pembangunan ketahanan keluarga. Jakarta: Kementerian Pemberdayaan Perempuan dan Perlindungan Anak Repulik Indonesia

Kementerian Pemberdayaan Perempuan dan Perlindungan Anak Repulik Indonesia (Kemenpppa RI). (2018). Pentingnya keabsahan anak. Retrieved from https://www.kemenpppa.go.id/index.php/page/read/31/ 1875/pentingnya-keabsahan-anak

Kementerian Kesehatan Republik Indonesia. (2018a). Kerjasama multi sektor untuk menurunkan stunting dan eliminasi TB. Retrieved from http://www.depkes.go.id/article/view/18112300002/kerj asama-multi-sektor-untuk-menurunkan-stunting-daneliminasi-tb.html

Kementerian Kesehatan Republik Indonesia. (2018b). Situasi balita pendek (stunting) di Indonesia. Retrieved from

https://pusdatin.kemkes.go.id/article/view/18102500001 /situasi-balita-pendek-di-indonesia.html.

Kementerian Perencanaan Pembangunan Nasional Republik Indonesia/ Badan Perencanaan Pembangunan Nasional BAPPENAS. (2018). Rencana Aksi Nasional Pengembangan Anak Usia Dini Holistik Integratif (RAN PAUD HI). Jakarta: Kementerian Perencanaan Pembangunan Nasional Republik Indonesia/Badan Perencanaan Pembangunan Nasional (BAPPENAS).

Kurniati, E., Adriany, V., \& Yulindrasari, H. (2007). Pengembangan modul pelatihan sensitivitas gender untuk guru TK Laboratorium School UPI (Penelitian dan Pengembangan pada Guru TK Lab School UPI). Universitas Pendidikan Indonesia.

Miškeljin, L. (2013). Integrated policies for early childhood education and care-challenges and possibilities. Miomir Despotović Emina Hebib, 363.

OECD. (2004). Starting strong curricula and pedagogies in early childhood education and care: five curriculum outlines. Retrieved from https://www.google.com/url?sa=t\&rct=j\&q=\&esrc=s\&s ource $=$ web $\& c d=\&$ ved $=2$ ahUKEwjYxquric $\_p A h V H W$ X0KHbLCDuEQFjAAegQIBRAB\&url=https\%3A\%2F $\%$ 2Fwww.oecd.org\%2Feducation $\% 2$ Fschool $\% 2 F 31672$ 150.pdf\&usg=AOvVaw3rwqyS5rR3kOTjqrOJ8aeC

Penn, H. (2008). Working on the impossible. Childhood, 15(3), 379-395.
Pusat Data dan Statistik Pendidikan dan Kebudayaan. (2019). Angka partisipasi kasar pendidikan anak usia dini Tahun 2018/2019. Jakarta: Kementerian Pendidikan dan Kebudayaan.

Rejeki, S. (2011). Konflik pemangku kepentingan dalam pelaksanaan program pendidikan anak usia dini (PAUD) (Studi eksploratif tentang konflik pemangku kepentingan dalam pelaksanaan program pendidikan anak usia dini (PAUD) Sinar Pelangi di Kelurahan Semanggi, Kecamatan Pasar Kliwon, Kota Surakarta) (Bachelor Thesis), Universitas Sebelas Maret.

Rohita, R., Fitria, N., \& Nurfadilah, N. (2016). Implementation of early childhood development integrative and holistic (PAUD HI) in daycare. Paper presented at the 3rd International Conference on Early Childhood Education (ICECE 2016).

Swanborn, P. (2010). Case study research: What, why and how? London, California, India, Singapore: SAGE Publications

Wulandari, H., Supriyati, Y., \& Jalal, F. (2018). Evaluation of holistic and integrated program in early childhood education and development (PAUD HI). International Journal of Multidisciplinary and Current research, 6 .

Yulindrasari, H. (2012). ECCE in Indonesia: Policy and challenges - Part 1. Retrieved from http://www.childresearch.net/projects/ecec/2012_06.ht $\mathrm{ml}$ 